\title{
HUBUNGAN ASUPAN PROTEIN DENGAN OBESITAS PADA REMAJA
}

\author{
Beti Dwi Suryandari, Nurmasari Widyastuti ${ }^{*}$
}

Program Studi Ilmu Gizi Fakultas Kedokteran Universitas Diponegoro

Jl.Dr.Sutomo No.18, Semarang, Telp (024) 8453708, Email : gizifk@undip.ac.id

\begin{abstract}
Background : Obesity was a complex health problem that not only affected adults but also adolescents. Obesity in adolescents had increased risk of mortality in adulthood. Excessive food intake was one of the causes of obesity. Protein was macronutrient that correlated with obesity. The type of proteins also associated with obesity.Recent research showed that there was a relationship between dietary animal and plant protein intake with obesity.

Objective : The aim of the study was to determine correlations of protein intake with obesity in adolescents.

Methods : The research was held on SMP Kesatrian 2 Semarang in June 2015. Design of this study was crosssectional with 49 adolescents, aged between 12-14 years which selected by simple random sampling.The data taken were body weight, height and intake of protein. Bivariat analysis was using rank Spearman and Pearson.

Results : There was 28,6\% obesity in adolescents. The result showed 55,1\% subjects have sufficient total protein intake, 65,3\% subjects have excessive plant protein intake and 91,8\% subjects have excessive animal protein intake. In statistical analysis, there was significant correlation between total protein intake $(r=0.732 p=0.000)$, animal protein intake $(r=0.735 p=0.000)$ and plant protein intake $(r=-0.319 p=0.026)$ with body mass index $(B M I)$.

Conclusion : There are significant correlation between total protein, animal protein and plant protein with BMI. Keywords :adolescents, obesity, total protein intake, plant protein intake, animal protein intake
\end{abstract}

\section{ABSTRAK}

Latar Belakang : Obesitas merupakan masalah kesehatan kompleks. Remaja yang mengalami obesitas dapat memiliki peningkatan risiko kematian saat dewasa. Kelebihan asupan makan merupakan salah satu faktor penyebab terjadinya obesitas. Protein merupakan jenis makronutrien yang berkaitan dengan kejadian obesitas. Jenis protein juga berhubungan dengan obesitas. Penelitian terbaru menunjukkan bahwa terdapat hubungan asupan protein hewani dan asupan protein nabati dengan obesitas.

Tujuan : Mengetahui hubungan antara asupan protein dengan obesitas pada remaja.

Metode : Penelitian ini dilaksanakan di SMP Kesatrian 2 Semarang pada bulan Juni 2015.Desain penelitian crosssectional dengan subyek 49 remaja usia 12-14 tahun dipilih dengan metode simple random sampling. Data yang diambil adalah berat badan, tinggi badan dan asupan protein. Analisis bivariat dengan uji rank Spearman dan Pearson.

Hasil : Terdapat 28,6\% remaja mengalami obesitas. Hasil penelitian menunjukkan 55,1\% subjek memiliki asupan protein cukup, 65,3\% subjek mengkonsumsi protein nabati melebihi kebutuhan dan 91,8\% subjek mengkonsumsi protein hewani melebihi kebutuhan. Terdapat hubungan signifikan antara asupan protein total $(r=0.732 p=0.000)$, protein hewani $(r=0.735 p=0.000)$ dan asupan protein nabati $(r=-0.319 p=0.026)$ dengan IMT.

Kesimpulan : Asupan protein total, protein hewani, protein nabati memiliki hubungan signifikan dengan IMT.

Kata Kunci : remaja,obesitas, asupan protein total, asupan protein nabati, asupan protein hewan

\section{PENDAHULUAN}

Obesitas merupakan masalah kesehatan kompleks yang saat ini tidak hanya diderita oleh kelompok dewasa tetapi juga kelompok remaja. Obesitas pada masa remaja merupakan masalah kesehatan serius karena prevalensi yang terus meningkat baik di negara maju ataupun negara berkembang. World Health Organization (WHO) menyebutkan bahwa prevalensi remaja dengan Indeks Massa Tubuh (IMT) >2 SD (sama dengan persentil IMT 98) meningkat menjadi 6,7\% tahun 2010 dan diperkirakan akan meningkat semakin tinggi menjadi 9,1\% tahun $2020 .{ }^{1}$ Riset Kesehatan Dasar (Riskesdas) 2013 menyebutkan sebesar 2,5\% remaja di Indonesia mengalami obesitas. ${ }^{2}$ Penelitian oleh Martalina pada subjek remaja di kota Semarang tahun 2012 didapatkan hasil prevalensi obesitas remaja awal usia 12-14 tahun sebesar $13,11 \%{ }^{3}$

Masa remaja merupakan masa yang rentan terjadinya obesitas. Masa remaja adalah masa dimana terjadi perubahan biologis, psikososial dan kognitif yang dimulai selama masa pubertas dan berpengaruh secara langsung terhadap status gizi dan kebutuhan gizi remaja. ${ }^{4}$ Asupan makan yang melebihi kebutuhan dapat menjadi penyebab terjadinya obesitas. Obesitas dapat didefinisikan sebagai suatu ketidakseimbangan antara asupan energi dengan energi yang dikeluarkan. ${ }^{5}$ Seorang remaja dapat dikategorikan mengalami obesitas 
apabila IMT menurut kurva Centers for Disease Control and Prevention (CDC) $2000 \geq$ persentil ke-95. ${ }^{6}$

Obesitas yang dialami remaja memiliki dampak kesehatan yang serius. Remaja yang mengalami obesitas dapat memiliki peningkatan risiko kematian saat dewasa. Remaja yang mengalami overweight memiliki risiko yang lebih tinggi pada hiperlipidemia, hipertensi, resistensi insulin dan diabetes tipe 2 dansindrom metabolik. ${ }^{7,8}$ Risiko obesitas pada remaja dapat diketahui dengan melakukan pengukuran pada indikator obesitas yaitu pengukuran IMT. Pengukuran Indeks Massa Tubuh (IMT) merupakan metode yang sederhana, memiliki spesifikasi yang tinggi dan berkaitan dengan lemak tubuh sehingga IMT adalah metode yang tepat untuk mengetahui obesitas pada remaja. 9,10

Berbagai faktor dapat menjadi penyebab terjadinya obesitas, salah satunya adalah asupan makanan melebihi kebutuhan. Protein merupakan jenis makronutrien yang berkaitan dengan kejadian obesitas. Kebutuhan protein bagi remaja usia 9-13 tahun adalah $0.95 \mathrm{~g} / \mathrm{kgBB} / \mathrm{hari}$ dan 0,85 $\mathrm{g} / \mathrm{kgBB} /$ hari untuk remaja laki-laki dan perempuan usia 14-18 tahun. ${ }^{11}$ Proporsi asupan protein nabati adalah $60-80 \%$ kebutuhan protein dan protein hewani sebesar $20-40 \%$ kebutuhan protein. ${ }^{12}$ Tubuh manusia tidak dapat menyimpan protein secara berlebih sehingga jika asupan protein berlebih maka akan disimpan tubuh dalam bentuk trigliserida dan hal inilah yang menyebabkan kenaikan jaringan lemak yang akhirnya menyebabkan status gizi lebih. 13

Jenis protein juga berhubungan dengan obesitas. Penelitian terbaru mengungkapkan bahwa protein hewani menjadi jenis protein yang paling banyak dikonsumsi remaja. ${ }^{14}$ Konsumsi protein dari sumber hewani dapat berisiko terhadap resistensi insulin ${ }^{15}$ Kandungan asam amino arginin, histidin dan leusin yang terdapat dalam protein hewani dapat meningkatkan sekresi insulin dan berkaitan dengan metabolisme lemak. ${ }^{16}$ Penelitian oleh Yi Lin et al tahun 2015 menjelaskan terdapat korelasi positif antara asupan protein hewani dengan BMI $z$ score dan persen lemak tubuh. ${ }^{14}$ Berdasarkan hal tersebut peneliti tertarik untuk melihat hubungan asupan protein dengan obesitas pada remaja. Hasil penelitian ini diharapkan dapat memberikan informasi tentang keterkaitan asupan protein dengan obesitas pada remaja dan dapat digunakan sebagai rujukan untuk penelitian selanjutnya.

\section{METODE PENELITIAN}

Penelitian ini dilaksanakan di SMP Kesatrian 2 Semarang pada bulan Juni 2015. Penelitian ini termasuk dalam ruang lingkup keilmuan gizi masyarakat dengan desain penelitian cross-sectional.

Populasi terjangkau dalam penelitian ini adalah remaja usia 12-14 tahun di SMP Kesatrian 2 Semarang. Subyek dipilih berdasarkan kriteria inklusi, yaitu bersedia menjadi subyek penelitian dengan mengisi informed consent, subjek tidak memiliki Indeks Massa Tubuh (IMT) underweight ( $<5$ persentil), sehat dan tidak sedang dalam proses pengobatan dokter serta tidak sedang menjalankan diet tertentu. Subjek akan dikeluarkan dari penelitian bila sakit atau meninggal dunia saat penelitian berlangsung, mengundurkan diri menjadi subjek penelitian dan pindah sekolah. Berdasarkan perhitungan besar sampel yang dihitung menggunakan rumus estimasi proporsi, diperoleh jumlah sampel minimal sebanyak 49 sampel. Subyek sebanyak 49 orang dipilih menggunakan simple random sampling.

Variabel bebas dalam penelitian ini adalah asupan protein. Data asupan protein total, protein nabati dan protein hewani diperoleh diperoleh dengan melakukan wawancara menggunakan formulir Semi Quantitative Food Frequency Questionnaire $(S Q-F F Q)$. Hasil yang diperoleh kemudian diolah menggunakan program nutrisurvey. Data asupan protein kemudian dikategorikan menjadi kurang ( $<10 \%$ energi total), cukup (10-15\% energi total) dan lebih (>15\% energi total). ${ }^{17}$ Asupan protein nabati dikategorikan menjadi kurang ( $<60 \%$ kebutuhan protein), cukup (60-80\% kebutuhan protein) dan lebih $(>80 \%$ kebutuhan protein). Asupan protein hewani dikategorikan menjadi kurang $(<20 \%$ kebutuhan protein), cukup (20-40\% kebutuhan protein) dan lebih (>40\% kebutuhan protein). ${ }^{12}$

Variabel terikat adalah indeks massa tubuh (IMT). Data indeks masa tubuh merupakan data indeks massa tubuh tiap responden yang dihitung dari berat badan $(\mathrm{kg})$ per tinggi badan (meter) kuadrat yang kemudian dikategorikan berdasarkan persentil IMT/U Central for Disease Control Prevention (CDC)2000 yaitu normal (5-84 persentil), overweight $(\geq 85$ persentil)dan obesitas ( $\geq 95$ persentil). Data yang sudah diperoleh kemudian diolah dan dianalisis secara statistik menggunakan program komputer. Data-data tersebut diuji normalitasnya menggunakan uji Kolmogorof-Smirnov. Analisis univariat digunakan untuk melihat nilai minimal, maksimal, median, rerata, SD dan untuk mengetahui distribusi 
frekuensi dari semua variabel yang diambil baik variabel bebas maupun variabel terikat. Analisis bivariat dilakukan untuk mengetahui hubungan asupan protein dengan IMT. Analisis bivariat dilakukan dengan uji korelasi Pearson pada data berdistribusi normal dan uji rank Spearman pada data berdistribusi tidak normal.

\section{HASIL PENELITIAN}

Karakteristik Subyek Penelitian

Subjek pada penelitian ini berjumlah 49 orang yang terdiri dari $44,9 \%(n=22)$ remaja lakilaki dan 55,1\% $(\mathrm{n}=27)$ remaja perempuan. Subjek memiliki umur dari 12-14 tahun dengan median 14 tahun pada remaja laki-laki dan 13 tahun pada remaja perempuan. Rerata IMT pada remaja perempuan $(24,1 \pm 4,89)$ lebih tinggi dibanding dengan remaja laki-laki $(22,1 \pm 5,30)$.Hasil secara rinci dapat dilihat pada tabell.

Tabel 1. Nilai minimum, maksimum, median, mean, SD umur, berat badan, tinggi badan dan IMT pada subjek berdasarkan jenis kelamin

\begin{tabular}{lllllllll}
\hline \multirow{2}{*}{ Variabel } & \multicolumn{4}{c}{ Laki-laki $(\mathrm{n}=22)$} & \multicolumn{4}{c}{ Perempuan $(\mathrm{n}=27)$} \\
\cline { 2 - 8 } & Min & Max & Median & Mean \pm SD & Min & Max & Median & Mean \pm SD \\
\hline $\begin{array}{l}\text { Umur } \\
\text { (th) }\end{array}$ & 12 & 14 & 14 & $13,5 \pm 0,67$ & 12 & 14 & 13 & $13,3 \pm 0,61$ \\
BB (kg) & 41.7 & 84.5 & 51.3 & $54,5 \pm 1,10$ & 38.7 & 86.2 & 55.6 & $57,4 \pm 1,24$ \\
TB (cm) & 146.5 & 170.2 & 157.8 & $157,7 \pm 7,06$ & 145.1 & 165.0 & 155.4 & $154,2 \pm 5,03$ \\
IMT & 17.13 & 36.57 & 20.17 & $22,1 \pm 5,30$ & 16.0 & 31.66 & 22.6 & $24,1 \pm 4,89$ \\
$\left(\mathrm{~kg} / \mathrm{m}^{2}\right)$ & & & & & & & & \\
\hline
\end{tabular}

Data umur dan berat badan dalam penelitian ini berdistribusi tidak normal sehingga menggunakan median sebagai ukuran pemusatan dan sebasaran data menggunakan minimal dan maksimal. Data tinggi badan dan tinggi badan berdistribusi normal sehingga menggunakan mean/rerata sebagai ukuran pemusatan dan sebaran data menggunakan simpangan deviasi. Tabel 1 menunjukkan rerata Indeks Massa Tubuh (IMT) pada remaja perempuan $(24,1 \pm 4,89)$ lebih tinggi bila dibanding dengan IMT pada remaja laki-laki $(22,1 \pm 5,30)$.

Tabel 2. Gambaran status gizi remaja berdasarkan persentil IMT/U

\begin{tabular}{lccc}
\hline \multirow{2}{*}{ Jenis Kelamin } & \multicolumn{3}{c}{ Status Gizi } \\
\cline { 2 - 4 } & Normal $(\%)$ & Overweight $(\%)$ & Obesitas (\%) \\
\hline Laki-laki & $15(51,7)$ & $3(13,6)$ & $4(18,2)$ \\
Perempuan & $14(48,3)$ & $3(11,1)$ & $10(37,0)$ \\
Total & $29(59,2)$ & $6(12,2)$ & $14(28,6)$ \\
\hline
\end{tabular}

Tabel 2 menunjukkan dari 49 subjek terdapat 14 $(28,6 \%)$ subjek mengalami obesitas, terdiri dari 4 $(18,2 \%)$ remaja laki-laki dan $10(37,0 \%)$ remaja perempuan. Terdapat $6(12,2 \%)$ remaja mengalami overweight terdiri dari $3(13,6 \%)$ remaja laki-laki dan $3(11,1 \%)$ remaja perempuan.

\section{Asupan Protein}

Tabel 3 menunjukkan bahwa dari 49 remaja terdapat $27(55,1 \%)$ subjek memiliki asupan protein cukup dan $22(44,9 \%)$ subjek melebihi kebutuhan. Sebanyak $32(65,3 \%)$ subjek mengkonsumsi protein nabati melebihi kebutuhan dan $45(91,8 \%)$ subjek mengkonsumsi protein hewani melebihi kebutuhan.
Tabel 3. Gambaran asupan makan pada subjek

\begin{tabular}{llc}
\hline \multirow{2}{*}{ Asupan makan } & \multicolumn{2}{c}{ Subjek $(\mathrm{n}=49)$} \\
\cline { 2 - 3 } & $\mathrm{n}$ & $\%$ \\
\hline Protein Total & & \\
Kurang & 0 & 0,0 \\
Cukup & 27 & 55,1 \\
Lebih & 22 & 44,9 \\
Total & 49 & 100,0 \\
Protein Nabati & & \\
Kurang & 6 & 12,3 \\
Cukup & 11 & 22,4 \\
Lebih & 32 & 65,3 \\
Total & 49 & 100,0 \\
Protein Hewani & & \\
Kurang & 0 & 0,0 \\
Cukup & 4 & 8,2 \\
Lebih & 45 & 91,8 \\
Total & 49 & 100,0 \\
\hline
\end{tabular}


Tabel 4. Gambaran sumber protein hewani dan protein nabati pada subjek

\begin{tabular}{llll}
\hline Asupan & Min & Maks & Median \\
\hline Sumber Protein Hewani & & & \\
Daging merah (g/hari) & 0 & 26 & 10 \\
Unggas (g/hari) & 18 & 110 & 37 \\
Ikan (g/hari) & 10 & 74 & 17 \\
Telur (g/hari) & 12 & 63 & 24 \\
$\begin{array}{l}\text { Seafood (g/hari) } \\
\text { Produk olahan daging }\end{array}$ & 0 & 31 & 10 \\
(g/hari) & 6 & 87 & 26 \\
$\begin{array}{l}\text { Susu dan produk olahan } \\
\text { susu (g/hari) }\end{array}$ & 0 & & \\
\hline $\begin{array}{l}\text { Sumber Protein Nabati } \\
\text { Sayur (g/hari) }\end{array}$ & 16 & 400 & 28 \\
$\begin{array}{l}\text { Buah (g/hari) } \\
\text { Kacang-kacangan (g/hari) }\end{array}$ & 0 & & \\
Produk kedelai (g/hari) & 14 & 301 & 81 \\
\hline
\end{tabular}

Gambaran sumber protein pada tabel 4 menunjukkan sumber protein hewani yang paling banyak dikonsumsi remaja adalah unggas (daging ayam) sedangkan yang terendah adalah daging merah dan seafood (udang, cumi-cumi, kerang, kepiting). Berdasarkan besar kandungan protein yang terdapat dalam bahan makanan maka unggas menyumbangkan protein yang paling besar dalam total asupan protein hewani. Sedangkan sumber protein nabati yang memiliki kandungan protein terbesar yang dikonsumsi subjek berasal dari produk kedelai.

Tabel 5. Nilai minimal, maksimal, median asupan protein total dan protein hewani pada subjek

\begin{tabular}{|c|c|c|c|c|c|c|c|c|c|c|c|}
\hline \multirow{2}{*}{ Asupan } & \multicolumn{3}{|c|}{ Normal } & \multicolumn{3}{|c|}{ Overweight } & \multicolumn{3}{|c|}{ Obesitas } & \multirow[b]{2}{*}{$\mathrm{p}$} & \multirow[b]{2}{*}{$\mathrm{r}$} \\
\hline & Min & Max & Median & Min & Maks & Median & Min & Maks & Median & & \\
\hline $\begin{array}{l}\text { Protein } \\
\text { total }(\mathrm{g})\end{array}$ & 47.7 & 77.1 & 61.7 & 78.2 & 91.0 & 85.3 & 65.1 & 127.5 & 94.6 & 0.000 & 0,732 \\
\hline $\begin{array}{l}\text { Protein } \\
\text { hewani } \\
\text { (g) }\end{array}$ & 12.6 & 26.2 & 20.4 & 35.1 & 60.2 & 50.8 & 38.4 & 87.8 & 58.6 & 0.000 & 0,735 \\
\hline
\end{tabular}

Tabel 6. Rerata asupan protein nabati pada subjek

\begin{tabular}{clllll}
\hline Asupan & $\begin{array}{l}\text { Normal } \\
\text { Mean } \pm \text { SD }\end{array}$ & $\begin{array}{l}\text { Overweight } \\
\text { Mean } \pm \text { SD }\end{array}$ & $\begin{array}{l}\text { Obesitas } \\
\text { Mean } \pm \text { SD }\end{array}$ & $\mathrm{p}$ & $\mathrm{r}$ \\
\hline Protein nabati $(\mathrm{g})$ & $40,8 \pm 5,07$ & $35,0 \pm 10,92$ & $35,3 \pm 8,86$ & 0.026 & $-0,319$ \\
\hline
\end{tabular}

Data asupan protein total dan protein hewani berdistribusi tidak normal sehingga menggunakan median sebagai ukuran pemusatan. Berdasarkan tabel 5, dapat diketahui bahwa median asupan protein total pada remaja obesitas $(94,6 \mathrm{~g})$ lebih tinggi dibanding dengan remaja normal $(61,7$ g) dan overweight $(85,3 \mathrm{~g})$. Median asupan protein hewani pada remaja obes $(58,6 \mathrm{~g})$ lebih tinggi dibanding dengan remaja normal $(20,4 \mathrm{~g})$ dan overweight $(50,8 \mathrm{~g})$. Data asupan protein nabati berdistribusi normal sehingga menggunakan mean/rerata sebagai ukuran pemusatan. Rerata asupan protein nabati pada remaja obes $(35,3 \pm 8,86)$ lebih rendah dibanding dengan remaja normal $(40,8 \pm 5,07)$ tetapi lebih tinggi dibanding dengan remaja overweight $(35,0 \pm 10,92)$. Analisis bivariat menunjukkan hasil bahwa asupan protein total memiliki hubungan signifikan dan berkorelasi
positifdenganIMT $(\mathrm{r}=0,732 \mathrm{p}=0,000)$. Asupan protein hewani memiliki hubungan signifikan dan berkorelasi positifdenganIMT $(\mathrm{r}=0,735 \mathrm{p}=0,000)$. Asupan protein nabati memiliki hubungan signifikan dan berkorelasi negatif dengan IMT $(r=$ $-0,319 \mathrm{p}=0,026)$ pada remaja.

\section{PEMBAHASAN}

Hasil penelitian dari 49 remaja usia $12-14$ tahun di sebuah SMP di Semarang didapatkan 14 $(28,6 \%)$ subjek mengalami obesitas.Angka ini lebih tinggi dibandingkan dengan penelitian yang dilakukan pada remaja SMP di Semarang pada tahun 2012 dengan prevalensi obesitas 13,11\% sehingga terlihat adanya kecenderungan kenaikan kejadian obesitas pada remaja. ${ }^{3}$ Jumlah obesitas pada perempuan $(37,0 \%)$ dalam penelitian ini lebih tinggi dibanding obesitas pada laki-laki $(18,2 \%)$. 
Komposisi tubuh pada perempuan mengalami perubahan yang lebih signifikan dibanding pada laki-laki. Selama masa remaja, laki-laki mengalami penurunan lemak tubuh sebesar $12 \%$, sedangkan perempuan mengalami peningkatan $120 \%$ lemak tubuh. $^{4}$

Prevalensi obesitas pada remaja yang semakin meningkat setiap tahun menunjukkan bahwa masa remaja merupakan masa rentan terjadinya obesitas. Hasil penelitian ini menunjukkan terdapat hubungan signifikan antara asupan protein dengan IMT pada remaja. Asupan protein total pada remaja obesitas lebih tinggi dibanding dengan remaja normal dan overweight. Hasil penelitian ini sesuai dengan teori yang menyatakan apabila asupan protein berlebih maka asam amino akan mengalami deaminiase. Nitrogen dikeluarkan dari tubuh dan sisa-sisa ikatan karbon akan diubah menjadi asetil KoA yang dapat disintesis menjadi trigliserida melalui proses lipogenesis kemudian disimpan dalam tubuh. Hal inilah yang menyebabkan kenaikan jaringan lemak yang akhirnya menyebabkan status gizi lebih. ${ }^{13}$

Asupan protein pada subjek penelitian berasal dari bahan makanan sumber protein nabati dan protein hewani. Bahan makanan sumber protein nabati pada remaja berasal dari kacang-kacangan, produk kedelai (tahu,tempe), sayur dan buah. Satu satuan penukar dari kacang-kacangan (20 gram), tahu (110 gram) dan tempe (50 gram) mengandung 5 gram protein. Sayur dan buah juga mengandung protein tetapi dalam jumlah yang kecil. Satu satuan penukar sayuran B (bayam, brokoli,kangkung,dll) mengandung 1 gram protein sedangkan sayuran $\mathrm{C}$ (daun singkong, nangka muda,dll) mengandung 3 gram protein. Asupan protein nabati paling banyak yang dikonsumsi remaja adalah buah tetapi karena kandungan protein buah terdapat dalam jumlah yang kecil maka bahan makanan sumber protein nabati yang menyumbangakan kandungan protein terbesar adalah produk kedelai. Median asupan produk kedelai pada subjek sebesar 65 gram/hari. Jumlah ini masih kurang dari rekomendasi asupan protein nabati yaitu sebesar 2-3 satuan penukar dalam satu hari.

Bahan makanan sumber protein hewani yang sering dikonsumsi remaja meliputi daging merah (daging sapi,kambing), unggas (daging ayam,bebek), ikan, telur ayam, seafood(udang,cumi-cumi,kerang,kepiting), produk olahan daging (sosis,bakso) dan produk olahan susu (susu,keju). Satu satuan penukar daging ayam (55 gram) dan daging bebek (45 gram) mengandung 7 gram protein. Bahan makanan sumber protein hewani yang lain juga memiliki kandungan protein yang sama dalam satu satuan penukar. Berdasarkan hasil penelitian didapatkan bahwa bahan makanan sumber protein hewani yang paling banyak dikonsumsi remaja adalah unggas (daging ayam, bebek).

Protein merupakan komponen yang penting dari tubuh dan diperlukan untuk struktur tubuh dan beberapa fungsi tubuh. Kebutuhan protein bagi tubuh adalah $10-15 \%$ dari total energi dengan proporsi asupan protein nabati adalah $60-80 \%$ kebutuhan protein dan protein hewani sebesar 20$40 \%$ kebutuhan protein. ${ }^{12,17}$ Asupan protein dalam jumlah yang tidak sesuai kebutuhan akan menimbulkan efek merugikan bagi kesehatan tubuh.

Protein nabati secara alami merupakan protein yang rendah lemak jenuh, rendah kolesterol, mengandung serat dan karbohidrat kompleks. ${ }^{18}$ Sebagian besar bahan makanan sumber protein nabati merupakan incomplete proteins, tetapi sebuah teori menjelaskan bahwa salah satu sumber protein nabati yaitu kedelai mengandung asam amino yang disimpan dalam bentuk 2 globulin yaitu $11 \mathrm{~S}$ glycinin dan $7 \mathrm{~S} \beta$-conglycinin. ${ }^{19}$ Protein pada kedelai mengandung semua asam amino esensial untuk nutrisi manusia sehingga produk kedelai hampir sepadan dengan protein hewani tetapi mengandung lemak jenuh yang rendah.

Isoflavon adalah komponen bioaktif pada protein kedelai. Konsumsi kedelai yang mengandung isoflavon dapat menurunkan trigliserida di hati dan konsentrasi kolesterol. Efek ini dikaitkan dengan pengurangan aktivitas dari enzim lipogenic hati terutama glukosa 6 fosfat dehidrogenase, enzim malat, asam lemak sintetase serta asetil Ko.A karboksilase. ${ }^{19}$ Protein kedelai menguran gi trigliserida di hati dengan menghambat sintesis asam lemak di hati. Asetil Ko.A karboksilase, enzim yang mengkatalisis karboksilasi asetil Ko.A untuk membentuk malonilKoA adalah enzim yang penting dalam biosintesis rantai panjang asam lemak. ${ }^{20}$ Isoflavon juga dapat mengatur gen yang terlibat dalam biosintesis kolesterol dan homeostasis dengan meningkatkan HMG KoA reduktse dan tingkat mRNA HMG KoA sintase dan aktivitas reseptor LDL. ${ }^{21}$

Protein kedelai memiliki dua polypeptida yang berkaitan dengan metabolisme lemak yaitu $7 \mathrm{~S}$ globulin dan $\beta$ conglycinin. Polypeptida seperti 7S globulin menghasilkan penurunan plasma lipid serta meningkatkan pengaturan reseptor $\beta$ VLDL hati. Polypeptida $\beta$ conglycinin mengurangi kadar trigliserida serum dengan cara menekan sintesis asam lemak hati dan mempercepat beta oksidasi. ${ }^{22}$ $\beta$ conglycinin memiliki efek pada penurunan 
aktivitas asam lemak hepatik sintase dan peningkatan kegiatan dua enzim yang berkaitan dengan beta oksidasi asam lemak dan mRNA pada tingkat oksidasi acyl-KoA.

Saponin kedelai juga berkaitan dengan metabolisme lemak. Penelitian pada hewan dengan pemberian diet yang mengandung saponin kedelai (tanpa isoflavon) menunjukkan jumlah yang lebih rendah pada kolesterol plasma total, trigliserida dan rasio total kolesterol dan kolesterol HDL. Perubahan ini terkait dengan peningkatan ekskresi asam empedu pada feses.

Protein hewani merupakan protein yang mengandung sembilan asam amino dalam proporsi sempurna untuk tubuh manusia, sehingga disebut sebagai complete proteins. Makanan tinggi protein hewani dikaitkan dengan kandungan kolesterol dan asam lemak jenuh tinggi yang dapat memberikan efek yang buruk kesehatan dan berkaitan dengan obesitas. Kombinasi asupan protein hewani dan asam lemak jenuh dapat memicu terjadinya resistensi insulin. Bahan makanan sumber protein hewani mengandung asam amino arginin, histidin dan leusin dapat meningkatkan sekresi insulin dan berkaitan dengan metabolisme lemak. ${ }^{16}$

Insulin adalah hormon yang dihasilkan oleh sel $\beta$ pankreas yang fungsinya dapat menstimulasi lipogenesis yaitu melalui transport trigliserida ke jaringan adiposa. Insulin mempengaruhi proses sintesis adiposit trigliserida dari glukosa. Insulin mempercepat masuknya glukosa ke dalam sel adiposa. Insulin juga meningkatan ketersediaan dan serapan asam lemak dalam adiposit dan merangsang lipoprotein lipase. Pemecahan glikolitik glukosa seluler menyediakan sumber glycerophosphate untuk re-esterifikasi dengan asam lemak membentuk trigliserida. ${ }^{23}$ Monoacylglycerol diserap dan diacylglycerol digunakan untuk resintesis gliserol. Gliserol fosfat tidak digunakan dalam adiposit karena tidak mengandung enzim glycerol 3 fosfatase. Insulin menghambat lipase intraseluler yang menghidrolisis simpanan trigliserida menjadi asam lemak bebas dan gliserol sehingga memicu akumulasi trigliserida.

Uji multivariat telah dilakukan untuk melihat variabel yang paling berhubungan dengan obesitas pada remaja. Asupan energi, lemak, krbohidrat dan aktivitas fisik dikendalikan dengan uji multivariat dan didapatkan hasil bahwa asupan protein hewani merupakan variabel yang paling berhubungan signifikan dengan obesitas pad remaja.

\section{SIMPULAN}

Asupan protein total, protein hewani dan protein nabati memiliki hubungan yang signifikan dengan obesitas pada remaja.

\section{SARAN}

Pengaturan diet yang tepat berupa pemilihan makanan perlu diperhatikan oleh subjek penelitian. Bahan makanan sumber protein hewani yang baik dikonsumsi berasal dari ikan yang tidak banyak mengandung lemak jenuh dengan jumlah porsi 2-3 satuan penukar dalam satu hari atau sebesar 35 gram dalam satu satuan penukar. Rekomendasi bahan makanan sumber protein nabati dapat dikonsumsi sebanyak 2-3 satuan penukar dalam satu hari.

\section{DAFTAR PUSTAKA}

1. Rosati P, Triunfo S, Scambia G. Child Nutritional Status: A Representative Survey In A Metropolitan School. Hindawi Publishing Corporation: Journal of Obesity, 2013

2. Badan Penelitian dan Pengembangan Kesehatan Kementerian Kesehatan RI. Riset Kesehatan Dasar 2013. Kementerian Kesehatan RI: Jakarta. 2013.

3. Martalina Tri Kapriana. Asupan Tinggi Lemak Dan Aktivitas Olahraga Sebagai Faktor Risiko Terjadinya Hipertensi Obesitik Pada Remaja Awal. Journal of Nutrition College. Universitas Diponegoro,2012. $\mathrm{p}: 1-16$.

4. Stang J, Story M. Guidelines For Adolescent Nutrition Service Chapter 1: Adolescent Growth And Development. University of Minnesota. 2005. p:1-8.

5. Lee RD, Nieman DC. Nutritional Assessment. In : Nelms MN, Sucher Kathryn, editors. Nutrition Therapy and Pathophysiology. 2nd ed. USA-Cengage Learning.2010. p:258, 264

6. Barlow SE. The Expert Commitee. Expert Committee Recommendation Regarding The Prevention, Assessment, and Treatment of Child and Adolescent Overweight and Obesity: Summary Report. Pediatrics. 2007;120:S164-92.

7. Cali AMG, Caprio S. Obesity In Children And Adolescents. J Clin Endocrinol Metab.2008; 93:S31.

8. Daniels SR, et al. Overweight In Children And Adolescents: Patho-Physiology, Consequences, Prevention, And Treatment. American Heart Association: Circulation. 2005; 111:1999.

9. JJ Reilly, AR Dorosty, PM Emmett and The ALSPAC Study Team. Identifcation of the obese child: adequacy of the body mass index for clinical practice and epidemiology. International Journal of Obesity.2000;24,1623-1627.

10. Beatriz Minghelli, Carla Nunes,dan Raul Oliveira. Prevalence of Overweight and Obesity in Portuguese Adolescents: Comparison of Different Anthropometric Methods.N Am J Med Sci; 2013.p:653-659. 
11. Mahan LK, Stump SE, Raymond JL, editors. Krauses's Food \& The Nutrition Care Process. 13th ed. USA-Elsevier Saunders; 2012. p: 415-466; 1080.

12. Achmad Djaelani Sediaoetama. Ilmu Gizi untuk Mahasiswa dan Profesi. Jakarta: Dian Rakyat; 2000. p:34

13. Brosnan ME, Brosnan JT, Young VR. Protein. In Lanham SA, Macdonald IA, Roche HM, editors. Nutrition and Metabolism; The Nutrition Society Textbook Series. 2nd ed. Willey-Blackwell; 2011.p:72

14. Yi Lin, Theodora Mouratidou, Carine Vereecken, Mathilde Kersting,Selin Bolca, Augusto César F de Moraes, et al. Dietary Animal And Plant Protein Intakes And Their Associations With Obesity And Cardio-Metabolic Indicators In European Adolescents: The HELENA Cross-Sectional Study.Nutrition Journal.2015.p:1-11

15. Azadbakht L, Izadi V, Surkan PJ, Esmaillzadeh A. Effect of a High Protein Weight Loss Diet on Weight , High-Sensitivity C-Reactive Protein , and Cardiovascular Risk among Overweight and Obese Women: A Parallel Clinical Trial. International Journal of Endocrinology.2013.

16. Deborah Bujnowski, Pengcheng Xun, Martha L. Daviglus, Linda Van Horn, Ka He; Jeremiah Stamler. Longitudinal Association Between Animal And Vegetable Protein Intake And Obesity Among Men In The United States: The Chicago Western Electric Study. American Dietetic Association.2011;111:1150-1155

17. Rolfes SR, Pinna K, Whitney E. Understanding Normal and Clinical Nutrition. 8th ed.USA-Cengage Learning.2009.p: I-1.

18. Steen Celine, Noyes Tamasin. The Great Vegan Protein Book. USA-Fair Winds Press.2015.p:7-9

19. Sugano, Michihiro. Soy in Health and Disease Prevention. USA-Taylor \& Francis Group CRC Press. 2006.p:28-29

20. Lehninger, Albert L. Principles of Biochemistry. Worth Publishers; 1982. p:195-214

21. Xiao Chao Wu. Health Effects of Soy Protein and Isoflavones in Humans. The Journal of NutritionAmerican Society for Nutrition. 2008. p:1-6.

22. Velasquez Manuel T, Bhathena Sam J. Manuel T.Role of Dietary Soy Protein in Obesity. International Journal of Medical Sciences.2007 4(2):72-82

23. Gropper SS, Smith JL, Groff JL. Advanced Nutrition And Human Metabolism. $5^{\text {th }}$ ed. USA -Wadsworth, Cangage Learning; 2009. p:179-181; 209 